\title{
Men, Women, and Sustainability
}

\author{
Bobbi S. Low \\ University of Michigan
}

Daily, in the popular press, politics, and academe, we read and hear about environmental consequences of the combined effects of population growth and per capita consumption (e.g., Durning, 1994; Mello, 1994; MacKellar \& Hatcher, 1994). The Limits to Growth study of 1972 argued that current growth trends would reach serious limits, but that it was possible to alter patterns and "establish a condition of ecological and economic stability that is sustainable into the future." Since then, a number of environmentalists and political leaders have adopted sustainable development as a goal. The Brundtland Report in 1987 defined sustainable development as "development that seeks to meet needs and aspirations of the present without compromising the ability to meet those of the future."

Concepts of "sustainability," though they vary in details, always concern interactions of population numbers and resource use levels. When the "Northern" and "Southern" nations squared off at the Rio Conference in 1992, each side made valid points in the sustainability debate. A population's total impact on any environment is a combined effect of the number of individuals consuming (often seen as a problem of less developed nations, with high population growth rates) times the per capita consumption rate and the impact of consumption technology (problems of developed nations). Although what contributes most urgently to any particular problem will vary, ignoring either population numbers or per capita consumption can lead to incomplete analysis and misdirected action.

Thirty years ago, population growth was seen as the major problem in sustainable development. Many scholars felt that demographic transition

Please address correspondence to Dr. Low, School of Natural Resources and Environment, University of Michigan, Ann Arbor, MI 48109-1115.

Population and Environment: A Journal of Interdisciplinary Studies

Volume 18, Number 2, November 1996

CC 1996 Human Sciences Press, Inc. 
POPULATION AND ENVIRONMENT

theory (which noted that fertility tended to fall with industrialization in Europe in the nineteenth century) predicted a relatively easy path to reducing population growth through the simple spread of industrialization. Per capita consumption was not considered in early analyses; recognition of its relevance to sustainability is recent. Demographic transition theory has not proved to be as robust as we had hoped in predicting when and how fast fertility is likely to fall (e.g., Coleman \& Schofield 1986): industrialization in the developing world sometimes proceeds without fertility declines (Korea), and sometimes occurs after fertility declines (e.g., Thailand; Knodel et al, 1990). Further, fertility declines have routinely been accompanied by increases in per capita consumption.

Why? Here I will argue that in the evolutionary history of all living things, "more" has always been reproductively more profitable-either more babies, or better-provisioned (more consumptive) babies. This distinction is crucial: the most successful reproductive tactic in many environments is not to make the maximum number of offspring, but to make fewer, better-invested offspring. When lowered fertility produces greater lineage success through fewer, better-invested children (MacArthur \& Wilson, 1967; Low, 1993a; Low et al, 1992; Low \& Clarke, 1991; Voland, 1984; $1989 ; 1990)$, lowered fertility produces no solution to the population-consumption dilemma. Several scholars estimate that a child raised in the developed world today consumes 15 times the amount used by a child in the less-developed world. When this is true, a two-fold decrease in fertility, accompanied by a fifteen-fold increase in consumption, does not bode well for our ecological future. We need a new approach to understanding the relationships among resource consumption, fertility, and sustainability.

\section{BEHAVIORAL ECOLOGY OF FERTILITY AND CONSUMPTION: WHY THERE ARE PROBLEMS}

A behavioral ecological perspective provides new insights into the biological reasons why high fertility and consumption, the core of our sustainability difficulties, are hard to reduce. Behavioral ecology assumes that behavior is the product of genes and environment interacting. The relative importance of each may differ, and in fact we have little idea of the genetic components of most behaviors, in humans or in other species (e.g., Grafen, 1984). Behavioral ecology simply asks whether we can predict the kinds of behavior that are likely to be common, if we know about environmental conditions (including social conditions), and about how those conditions change actors' genetic costs and benefits. 
BOBBI S. LOW

Behavioral ecology, when applied to humans for the purposes of generating hypotheses, uses the central paradigm in biology: first, humans, like other living organisms, have evolved to maximize their genetic contribution to future generations through producing offspring and assisting nondescendant relatives; second, the particular strategies accomplishing such maximization will differ in specifiable ways in different environments; and finally, just as for other mammals, these strategies will typically differ between the sexes. All living things have evolved to acquire and use resources for survival and reproduction. The ways they do so are constrained by ecological conditions. Ceteris paribus, those individuals using efficient strategies leave more offspring in the next generation than their competitors. Efficient resource use for reproductive ends has been profitable for humans, too (e.g., see Hawkes, this volume; Low, 1993a).

There are four substantive areas in which behavioral ecology makes new or unexpected, testable predictions: [1] relationships between fertility and resource acquisition or consumption, and [2] how these relationships differ between the sexes, [3] how evolved genetic interests complicate solutions to large-scale problems, and [4] how evolutionarily novel environments complicate solutions to large-scale problems.

\section{[1] Consumption and Fertility Patterns}

When resources are extremely scarce, fertility for both sexes declines; there simply may not be enough calories to maintain the body and reproduce (a modern voluntary equivalent is amennorhea in women distance runners). More resources typically mean more, and better-provisioned, offspring. But were we to ask the first ten people we encounter what relationship, if any, exists between wealth and fertility today, I would bet that the answers would be "no relationship" or "a negative relationship" ("it's the poor who have the most kids") rather than a positive one. How do these relationships actually play out across societies?

For men in traditional hunter-gatherer and agricultural societies, resources and status do indeed lead to proximate success and greater reproduction. Results from contemporary societies are mixed (Low et al., 1992). Transnational data (Birdsall, 1980) show a negative aggregate relationship: more infants are born per thousand women in poor countries than in wealthy countries. Studies using proxy measures (years of education, for example) rather than actual resource control, and some census data using aggregate patterns (e.g., Pérusse, 1992) also find negative results (reviewed by Low \& Clarke 1992). But studies which examine lineages (e.g., Mueller, 1991; Low, 1989a; 1990a; 1991; 1994a; Low \& Clarke, 1992; Hughes, 
1986), individual patterns (Rank, 1989), and some census data (Daly \& Wilson, 1983:334) tend to find a positive correlation between wealth and fertility (but see Kaplan et al. in press). Today, contraception technology complicates the issue. The functional basis of resources leading to fertility probably has not changed; when sexual access, rather than fertility, is measured, richer men today clearly have more sexual access than poorer men, even in societies in which the resources-fertility relationship is absent or negative (Pérusse, 1992).

A critical variable for predicting fertility is whether a child's eventual effectiveness in obtaining resources requires heightened investment (especially monetary) by parents in individual children. When it does, we predict declining fertility, but when it does not (in many proto-industrialized and other labor markets using unskilled labor), fertility decline is not expected. Such predictions are consistent with Knodel et al.'s (1990) finding that as education increases, fertility declines. Thus, even though the general pattern reported across countries is that fertility declines with increasing GNP, within such societies or social groups, when men's fertility is considered, fertility typically increases with increasing resources (above). In Birdsall's (1980) analysis, for example, within the countries for which she had data, the richest fifth of families never had lower total fertility than the poorest fifth-and they had far greater resources available for each child. In other words, increasing GNP is probably simply a correlate of cultural/technological/economic changes that result in a requirement for increasing investment in individual children to ensure their success.'

There exists a wealth of supporting evidence from biological studies, that, while simplistic in the context of human societies, may be useful. MacArthur and Wilson (1967, pp. 145-150), in examining the role of conspecific competition (i.e., competition among members of the same species), noted a potent change in the direction of natural selection, depending on the density of conspecific competitors. They argued that, when the density of conspecific competitors was low, selection favored "productivity," and the competitive efficiency of offspring was relatively unimportant to their eventual success. Under such circumstances, parents did best who simply maximized their fertility. As the environment filled up with competitors (a comparatively dramatic process on small islands, the focus of their investigation), selection shifted to favor the production of more competitive (better-nourished, better-taught) offspring, at the expense of number of offspring. As this occurred, parents did better who shunted resources into offspring investment, even at the expense of offspring numbers. Net lifetime reproduction was enhanced not by high fertility, but by lowered fertility - producing fewer but better-invested offspring. MacArthur 
BOBBI S. LOW

and Wilson named these two conditions " $r$ " and " $K$ " selection, after the areas of the logistic curve at which we would predict these conditions to be manifested. Something of an ecological fad followed, with wide misuse of the theory, so that whole species were sometimes described as $r$ - or $\mathrm{K}$-selected, muddling the important central question: What is the comparative advantage to parents of better-invested, highly competitive offspring versus more numerous offspring? Darwin $(1871$ : Vol. 1,319$)$ himself found this question central:

The only check to a continued augmentation of fertility in each organism seems to be either the expenditure of more power and the greater risks run by the parents that produce a more numerous progeny, or the contingency of very numerous eggs and young being produced of smaller size, or less vigorous, or subsequently not so well nourished.

In nonhuman species, the ecological and life-history responses to this selection are relatively simple. For example, small organisms, with high or uncertain adult mortality and thus uncertain ability to give effective parental care, are likely to produce larger numbers of offspring than organisms in which adults are relatively safe and long-lived. Organisms with "safe" parents and uncertain food supplies, and those in which parental teaching affects offspring effectiveness (e.g., vertebrate predators), have fewer offspring than those in which parental investment is less effective.

Across species, these patterns seem to be of relatively little help in formulating theory. But consider the diversity within human societies, which in fact corresponds to MacArthur and Wilson's original argument. In many traditional societies, with few or no medical facilities, fertility is by far the strongest correlate of net lifetime reproductive success, and in such societies men typically strive for resources and status, using these directly in reproductive ways; in fact, the training of boys in these societies is related to their potential reproductive gains from striving.

On the other hand, complexities in either the ecological or the social environment that result in increased effectiveness of parental investment should result in more investment, at the expense of fertility itself (see KapIan 1995, who explores this specifically in the market economy context). The degree of this shift should be influenced by resource richness: if resource richness increases as the importance of investment increases, the negative impact on fertility will be moderate; if resource richness decreases as the importance of investment increases, the negative impact on fertility will be severe. The extent to which we can predict fertility shifts as a result 
of changing economic conditions or purchasing power will depend on a number of factors, but especially on how much parental investment assists individual children. In many cases, this may hinge on whether individuals are wage- or market-dependent. Resource differentials, opportunities for better-educated children, and migration options in less developed nations are also important. In less developed countries, we may find that as resources begin to decrease, the risks of migration will be perceived as less onerous. Out-migration seems likely to increase if it can offer individuals an alternative to decreasing fertility.

Existing evidence suggest that human fertility decisions arise from individual self-interest (not even conscious); yet demographers frequently assume rationality and concern for the population (e.g., Coale, 1986, p. 7; Wrigley, 1978; Dupâquier, 1972; Schofield, 1976; Viazzo, 1990). Strategies that enhance individual success will always be favored by natural selection, regardless of their effect on others and on the population (e.g., Fisher, 1958; Williams, 1966; Dawkins, 1982; 1989; Daly \& Wilson, 1983; Krebs \& Davies, 1991). Thus, the apparent "regulation" of human populations is an emergent phenomenon (Low, 1993a; Low et al., 1992), because: [1] many families, differing in their resources, attempt to optimize their own fertility in varying conditions, or [2] subgroups impose legal or religious coercion. These two fertility responses are functionally quite different. The extent to which restrictions impose costly constraints on individual optimization may predict the extent to which individuals will resist them (e.g., China's one-child policy). it would be rewarding to explore empirically when fertility shifts arise from ordinary selection, versus coalition-imposed fertility shifts. Yet we must distinguish among these functionally different patterns. Recently Hawkes and Charnov (1988; see also Botkin, 1990) have cogently summarized the arguments.

Thus, 1 think we have a muddle in current thought about fertility, wealth, and consumption, and how these relate to sustainable development; probably several things contribute. First, quite different things may be measured and inappropriately compared. Aggregate national comparisons such as TFR (total fertility rate) and GNP/capita (gross national product per capita) have additional problems. In the biological comparisons, variance is critical; aggregate measures such as GNP and TFR mask all variance. Further, TFR, for example, is the total number of children that would be born per thousand women if all women lived all the way throughout their reproductive lifetimes and had the average number of children at each age; it thus ignores both infant and women's mortality (both of which are higher in poorer countries-no wonder fertility looks higher there). What measure is appropriate depends on the questions we 
wish to ask, and we have, in the past, paid insufficient attention to this problem.

Second, if individual fertility is shaped by natural selection to respond to ecological conditions such as fluctuations in resources, then population patterns should be correlated with external conditions. Fertility patterns in noncontraceptive societies in fact make ecological sense (see Low, 1993a); and the nineteenth century European decline in fertility called "The" demographic transition was in fact variable, and dependent on local resource conditions (Low et al. 1992), for the reasons reviewed above. It may be true that, other things being equal, greater fertility means greater lineage success; yet "other things" are seldom "equal." Conditions in which increased investment in individual children enhances their competitiveness - their ability to survive, marry, and reproduce-favor parents who shift resources from production of further children to additional investment in existing children (Low, 1993a). Unless there is a net increase in total resources, the allocation of available resources must be into fewer children (e.g., lower fertility, higher lifetime success; Rogers, 1990; 1992). Thus, if parental resources can reduce mortality, or make children likelier to get established and marry, lower fertility and higher per-child investment (e.g., in education) will be favored. Lowered infant mortality, leading to increased population density (and increased competitiveness; MacArthur \& Wilson, 1967), and industrialization are often cited as "causes" of the demographic transition. Neither is either necessary (e.g., Knodel et al., 1990) or sufficient to produce a decline in fertility. There are many conditions that can make it more expensive to produce effective, competitive children (Low et al., 1992; Low \& Clarke, 1992).

Perhaps because of the costliness of children, people make conscious decisions about fertility versus investment. Families in modern societies make deliberate decisions about family size in response to their judgment of available resources (Freedman \& Thornton 1982; Johnson \& Lean, 1985); when deliberately-chosen family sizes are considered, income and family size are positively correlated. Accidental pregnancies complicate the picture. When people judge their income as favorable compared to others, fertility increases (Freedman \& Thornton, 1982; Johnson \& Lean, 1985; Turke 1989); women on welfare (Rank, 1989) clearly avoid further pregnancies in order to invest more effectively in existing children. In fact, as Lancaster and Lancaster (1987) argue, perception of resources has probably influenced fertility decisions throughout human evolution.

In evolutionary terms, children are a net cost economically, and a net benefit genetically. What if, as some economic demographers (e.g., Caldwell, $1976 ; 1983)$ argue, children were also a net economic gain for par- 
ents in pre-industrial and pre-demographic transition societies? So far, all analyses of actual data suggest that although the situation is complex, children's labor is never sufficient to result in a net caloric/economic gain to parents (Turke, 1989; 1992; Kaplan, 1995). Parents provide for their children, even in societies in which children provide some work; even grandparents provide for their grandchildren (e.g., Turke, 1988; Hawkes et al., 1989). If children were perceived by parents as producers in agricultural work, not only land owners but land workers should have higher fertility. Yet this is not true where it has been studied; only land owners typically have higher fertility and larger resulting families no matter what the economic times; and landowners' family size shows less variance than that of nonlandowners (Low \& Clarke, 1992; Pfister, 1989a; b; Cain, 1985; Mclnnis, 1977; Hayami, 1980; Hughes, 1986; Voland, 1990).

\section{[2] Our Mammalian Heritage: Why the Sexes Differ}

Beyond the general problem of how resource consumption influences fertility in different environments, there are sex differences in resource striving. In mammals, including humans, male and female patterns differ, and behavioral ecology, based as it is on natural selection theory, may help us understand where these sex differences come from, and why they continue to exist.

Behavioral ecology views organisms as "packages" of calories to be spent and risks to be taken. At any moment, an organism can spend its effort on maintaining its soma, or body (somatic effort: thermoregulation, eating, metabolizing, etc.); or it might spend reproductive effort, either in attracting a mate (mating effort) or in caring for offspring (parental effort). In any described environment, some patterns of expenditure will be better than others in their effect on survival and reproduction. The allocation of somatic and reproductive effort relates to the problems of surviving and reproducing relatively better than one's competitors. In most species, it pays individuals to specialize in either mating or parental effort-the behaviors that make one successful in mating are often strongly opposed to the behaviors that promote parental success (reviewed by Low, 1993a; also Daly \& Wilson, 1983). In most, but not all, species, mating specialists are likely to be male, and parental specialists are likely to be female.

This specialization has profound implications that are not immediately obvious. If one sex specializes in getting mates, and the other in investing in offspring, we predict very different sorts of behaviors between the sexes. Mating and parental effort show very different "return curves" (Figure 1). Mating effort has a very high fixed cost-typically, a male must establish 
BOBBI S. LOW

FIGURE 1. Mating and parental effort have different return curves. Mating effort has a high fixed cost, making failure frequent, and great expenditure and risk potentially profitable; parental effort has a more linear return and a lower maximum. As a result, the behaviors that are most effective in each kind of effort are contradictory (modified from Low 1993a).

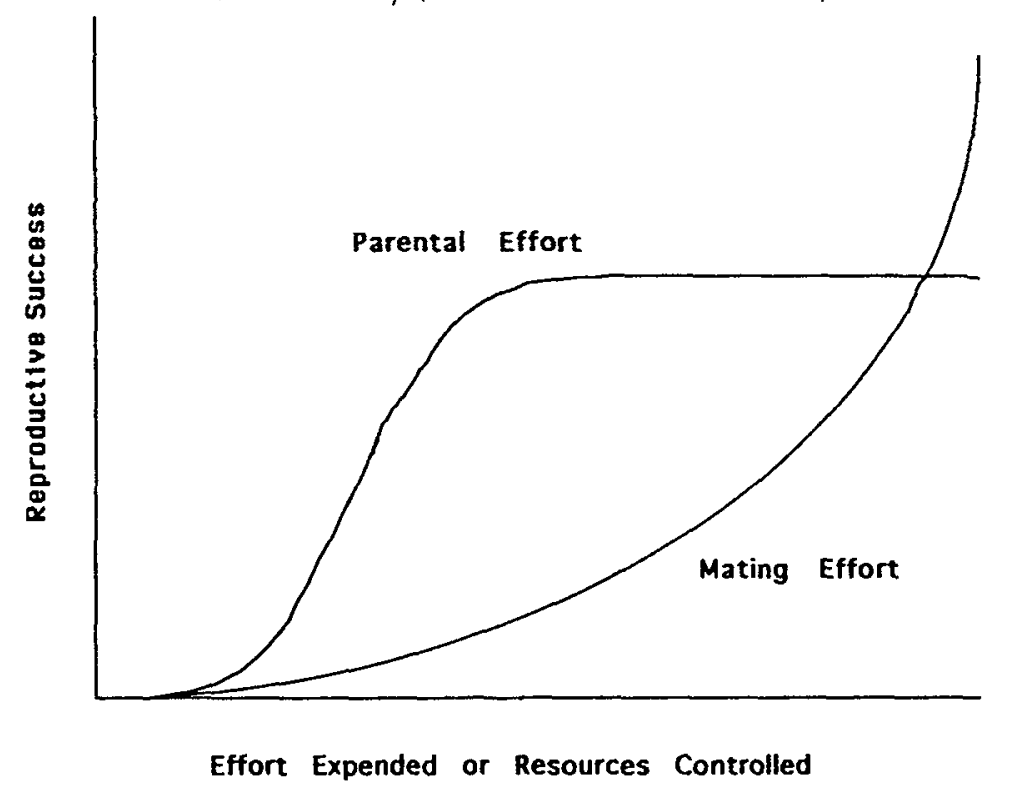

himself as successful before he can get even his first mate, and this is typically expensive and risky. However, his reproductive returns continue to grow with continued resource acquisition. Parental effort shows a more linear return curve: each additional offspring is likely to cost about as much as the first. Furthermore, female fertility is more limited than male fertility because of this fact. This simple observation has profound impact on male, versus female, behavior in most species. Far fewer males than females actually reproduce, but the most successful male can have an order of magnitude more offspring than the most reproductively successful female. For example, among elephant seals, over $80 \%$ of males fail to reproduce; the most reproductive female had 11 offspring in her lifetime, while the most successful male had over 90 (LeBoeuf \& Reiter, 1988).

Since males typically experience more variance in reproductive performance than females, the stakes are higher for them. Since high expenditure and risk-taking may be profitable, risky behavior and conflict are, in polygynous species, male endeavors. As a result, sexual conflicts (more 
frequently by males in mammals) are more likely to escalate to lethal proportions than conflicts arising from other sorts of individual selection. Since male reproductive variance typically exceeds female reproductive variance in humans also (see Low, 1990b), a series of predictions about sex differences in risk-taking, promiscuity, and aggressiveness follows. ${ }^{2}$ The return curve differences for male and female mammals have a profound impact on general resource-consumption patterns: males and females experience quite different payoffs both for their accumulation of resources and for their acceptance of risk. This underlying difference sets the scene for widespread, predictable sex differences, even across cultures-differences that strongly affect fertility and consumption patterns.

Male Cultural and Reproductive Success: The Influence of Resource Value. When resource-controlling men can have higher fertility than others (e.g., through polygyny in bride-price societies), fertility will tend to be high but variable. Such conditions obtain in many traditional societies and some pre-and proto-industrial societies (e.g., Pfister 1989a; b). In fact, in quite a variety of societies, wealth or status and reproductive success are positively correlated for men (e.g., Hill, 1984)). Richer Turkmen had more wives and more children than poorer men (Irons, 1979). In the pastoral Mukogodo of Kenya, wealth enhances men's reproductive success (Cronk, 1991a). Similarly, the Meru use livestock for bridewealth, and richer men can marry more wives (Fadiman, 1982). In societies as diverse as the Hausa (Barkow, 1977), Trinidadians (Flinn, 1986), and Micronesian islanders (Turke \& Betzig, 1985), status and wealth correlate with male reproductive success.

In some societies, such as the Ache (Hill \& Kaplan, 1988; Kaplan \& Hill, 1985) and the Yanomamö (Chagnon 1979; 1982; 1988), few physical resources are owned; even here, status represents a resource. Among the Ache, men who are good hunters not only get more matings than other men, but their children survive better (Hill \& Kaplan, 1988). In the Yanomamö, male kin available for coalitions also represent a resource, and men manipulate kinship terms in ways that make more women available for mates, and render powerful men available as coalition partners (Chagnon, 1982; 1988), so that reproductive success is uneven. Among the Yanomamö, the most successful methods of gaining wives are being a member of a powerful kin group, and gaining recognition as a revengekiller (Chagnon, 1988; also see below "Sex Differences in Homicide and Warfare"). Among the polyandrous Toda, a man's centrality in the kinship network is related to his reproductive success (Hughes, 1988). 
BOBBI S. LOW

Women's Age: The Importance of Reproductive Value. If the capacity to provide resources has been important for men in human evolutionary history, the critical variable for women appears to have been childproducing capacity, or reproductive value. Reproductive value, an index derived from age-specific fertility and mortality rates, is defined as the probable number of daughters a female will have in the rest of her life, thus encompassing age-specific fertility and survivorship functions. In societies with bride price or some other exchange of goods at marriage $(74 \%$ of the Standard Cross-Cultural Sample), younger women are expected to command a higher bride price. If high reproductive value is desirable, men with greater economic resources may be able to command women with higher reproductive value in the marriage market.

An interesting social dilemma follows. Poor men might choose to marry older women with greater resources when they can, explicitly trading reproductive value for resource value. Thus in eighteenth and nineteenth century Scandinavia, daughters of upper-middle class men (who would marry richer men) were considered marriageable at eighteen years, while daughters of poorer men, who would marry poorer men, were not considered marriageable until years later, in their mid-to-late twenties (Drake, 1969; Low, 1991). Richer men, in marrying younger women, gained high reproductive value, but provided resources themselves. Hughes (1986) found similar correlations between men's wealth and women's reproductive value in England.

Remarriage for Widows and Widowers. Resources and reproductive value interact in remarriage patterns as well. In most societies, widows commonly remarry far less frequently than widowers; no obvious sociological or economic explanation exists. When women remarry, they do so at younger ages (higher reproductive value) than men; women's probability of remarriage declines with age, as reproductive value declines. Classical demographers (e.g., Knodel, 1981, Knodel \& Lynch, 1985) were puzzled by such patterns, for women's economic value, like men's, does not decline with age. However, women's reproductive value does decline, and the decline after its peak is a certainty (declining fecundability).

In many societies, though the pattern can be slightly modified by the operant sex ratio (Imhof, 1981), the patterns are quite strong: widows remarry far less frequently than widowers (Akerman, 1981; Cabourdin, 1981; Corsini, 1981; Bideau \& Perrenoud, 1981); widows with dependent children remarry at an even lower rate (e.g., Bideau, 1980; Corsini, 1981; Bideau \& Perrenoud, 1981; Griffith, 1980); and older widows commonly 
do not remarry at all (e.g., Cabourdin, 1981). These patterns persist in contemporary society (Glick \& Lin, 1986; Hill \& Low, 1991). Not surprisingly, when men remarry, they tend to marry younger women (of higher reproductive value). This contributes to the greater fertility of men's second marriages, compared to women's, even in societies with late ages at first marriage and socially-imposed monogamy.

Training Boys Versus Girls. The conditions described above represent a selective background favoring specific differences in men's and women's behavior. We expect strong differences between the sexes across cultures (e.g., Whiting \& Edwards, 1973; Whiting \& Whiting, 1975; Rosenblatt \& Cunningham, 1976). Males more frequently than females have succeeded by openly and aggressively competing in coalitions for power and resource control. We expect men to strive for large amounts of resources, to exert overt efforts to change rules, to manipulate rules, and to change coalitions. If women have seldom or never been able to profit reproductively from such actions, we expect them to behave in ways which will maximize the probability of continuance of the current coalition, although not to eschew subtle attempts at manipulation.

It follows that parents should bring up children of the two sexes differently, and that these differences should be exaggerated or minimized, depending on the nature of the society, and thus the likely reproductive consequences. In particular, we expect that sons will be more strongly trained than daughters in behaviors useful in open competition, while daughters will be more strongly trained in such values as sexual restraint, obedience, and responsibility - traits sought by men in wives. Reexamination of Barry et al.'s (1976) cross-cultural data on how boys and girls are trained (Low, $1989 \mathrm{~b})$ suggests that both predictions are true. Further, sons are more strongly trained in attributes like aggression and fortitude in those societies in which the reproductive stakes are highest (polygynous societies), and lowest in rigidly stratified societies, in which individual striving is least likely to reap reproductive rewards.

Across all societies, boys are taught, in early and late childhood, to show more fortitude and be more self-reliant than girls (Low, 1989b). Girls are taught, in early and late childhood, to be more industrious, responsible, obedient, and sexually restrained than boys. The greater the degree of polygyny, measured as per cent of men and per cent of women polygynously married (cf. Low, 1988), the more older boys are taught to show fortitude, aggression, and industriousness (Low, 1989b). As the maximum harem size allowed increases (cf. Betzig, 1986), so does intensity of train- 
ing for boys to show fortitude, industriousness, responsibility, and obedience.

In our society children themselves quickly show sex differences in perceptions of dominance and aggression. By age three, boys play in groups and play more aggressive games than girls (Freedman, 1974; Omark \& Edelman, 1976). By age four, boys tend to advertise themselves as toughest (Ormark \& Edelman, 1976); by age six, they have formed dominance hierarchies, perceive them accurately, and attempt to manipulate their position in them-while girls find the entire question irrelevant! Cross-culturally, the more women actually control important resources or exercise power, the less daughters are taught to be submissive. For example, the more women are able to inherit property, the less daughters are taught to be obedient. In societies in which women can hold political office, daughters are more strongly inculcated in achievement and striving than in societies in which women cannot hold office, although the difference is only marginally significant. The more authority women have over children older than four, the less daughters are taught to be obedient (Low, 1989b). Thus, the behavioral ecology of resource competition predicts important patterns of child training across cultures, and specific differences between the sexes.

Abortion, Infanticide, and Abandonment. Patterns in parental termination of investment in children, such as abortion or infanticide, are also resource related, and show sex differences in most cultures. In nonhuman species, it is typically not parents, but reproductive competitors (e.g., males taking over a harem), who commit infanticide (Hrdy, 1974; 1978; 1979; Packer \& Pusey, 1983; 1984). In humans, also, genetic relatedness is important; step-parents are more likely to abuse or neglect children than own parents (Daly \& Wilson, 1984; 1985; 1987). Even when socioeconomic factors are taken into consideration, the risk for babies of being killed is seventy times as great if the child lives with a step-parent as well as its natural parent. Among the Tikopia and the Yanomamö, a man may demand the death of his new wife's prior children. Such cases dramatically reflect the conflict of genetic interests between the parent and the nonparent who may be called upon to invest in the children.

Yet parents do commit infanticide, abortion, and abandonment, under specific conditions. Because each infant requires great investment, investment biases, even to the extent of infanticide, can be reproductively profitable. Natural selection can favor termination of investment, depending on: mother's ability to invest, mother's access to additional resources (such 
as family, mate), child's ability to succeed, and the economic and reproductive value of other existing or future possible children. Crossculturally, deformed or seriously ill newborns are at greater risk for infanticide. Similarly, when circumstances reduce a mother's chance of successful investment (e.g., too-close births, twins, lack of an investing male), infanticide or neglect is more likely (Daly \& Wilson, 1988; Bugos \& McCarthy, 1984). Abortion, too, appears more common in circumstances in which the birth of an additional child is likely to reduce the mother's lifetime reproductive success. As women age, and their reproductive value declines, termination of investment is less likely (Hill \& Low, 1991). Even attitudes toward abortion in our society are related to the proportion of women in any group who are "at risk" of unwanted pregnancy (Betzig \& Lombardo, 1991).

In many societies, there is a sex preference in infanticide; however, this represents a conundrum if it becomes widespread and persistent, for the rare sex comes to be more valuable in any marriage market (Fisher, 1958 , p. 159). In hypergynous societies, in which women may marry "up" and men "down," but the reverse is not allowed, daughters are valuable to lower-class families, but costly to upper-class families, and infanticide tends to be female-biased in high-status families (e.g., Dickemann, 1979). It is possible, too, that (otherwise rare) male-biased infanticide occurred in high-status families (Parry, 1979).

Historical studies of child abandonment also reflect such selective considerations as a mother's ability to invest in the child (including own health, familial resources, economic conditions), and the child's health, legitimacy, and sex. Child abandonment in historical France (Fuchs, 1984), Spain (Sherwood, 1988), and Russia (Ransel, 1988) was related to economic factors, child's condition, and mother's abilities. Similarly, in Boswell's (1990) well-known historical overview of child abandonment $77 \%$ $(49 / 63)$ of his cases were related to maternal ability to invest and offspring quality. Perhaps the other side of the coin is represented by adoptiontaking care of someone else's child. Crossculturally, when someone adopts a nonrelated child, most often it is a poorer, or lower-status family offering to care for the child of a richer, more powerful lineage.

Voland (1984) examined the effect of father's status on children's survival in a nineteenth-century German parish. The overall sex ratio of children born was almost exactly even; the effect of mother's age was not analyzed. Deaths during the first year of life due to parental neglect were status-related: for farmers, daughters were likely to be considered less desirable than sons; for other classes, the reverse appeared to be true. Voland thus has evidence of uneven parental investment tied to the perceived value of each sex for parents in different classes. In a similar sample from 
BOBBI S. LOW

nineteenth century Sweden, I found (Low $1991 ; 1994$ b) no bias in the birth sex ratios of children born to richer versus poorer men, but a very strong sex bias in investment by rich men versus poor men; both kinds of fathers produced more rich sons than rich daughters-but poor men dramatically funneled their (more limited) resources into sons.

Sex-Biased Inheritance. Because resource control is an effective and widespread strategy for men in acquiring mates, sex biases in resource inheritance are important; they can influence survivorship and likelihood of reproduction. Perhaps no other species exhibits the degree of resource transfer that can take place through inheritance within human families. Inheritance is frequently biased by sex, legitimacy, and birth order.

In societies with heritable goods, the size of a family and the sex of siblings may differentially influence men's and women's ability to marry at appropriate times. Within polygynous marital systems, inheritance is strikingly male-biased (Hartung, 1982), precisely the pattern predictable if male reproductive success varies more than female reproductive success, and male success is influenced by resource control. In many societies, earlier-born sons tend to inherit the greatest proportion of the resources, even where more equal distribution is stipulated by law (e.g., nineteenth century Sweden). There is evidence of such influences at work in societies as diverse as medieval Portugal, nineteenth century Sweden, and the contemporary United States (Low, 1991; Boone, 1986; 1988; Abernethey \& Yip, 1990).

Sex Differences in Homicide and Warfare. Lethal conflict is an extreme form of striving. Behavioral ecology predicts that possibly-lethal conflict will occur when the potential reproductive rewards (mates, status, resources for mates) are high; and that, within mammals, males will more often be in a position to gain than females (Manson \& Wrangham, 1991; Alexander, 1987; Low, 1993b). Sexual selection (in competition over mates) and kin selection (in infanticide and intergroup conflicts; Shaw, 1985; Shaw \& Wong, 1989) are the driving forces.

Coalitions of males in nonhuman mammals are riskier, more aggressive, and more often among nonrelatives than coalitions among females (Low, 1990a; 1993b). Females' conflicts center on food or parental resources, while males' conflicts are likely to center on the acquisition of mates. Because of these patterns, the reproductive impact of conflict for male mammals may be many times greater than that for females. Thus it is not surprising that aggression over resources is one of the most consistent sex differences across cultures (Ember, 1981; Barry et al., 1976; Low, 
1989b), and homicides are principally a male endeavor (Daly \& Wilson, 1988). Crossculturally, men can make enormous direct reproductive gains with access to power, status, and great amounts of resources, but it is not clear to what extent women can do so (above); this parallels the reproductive ecology of resource control and status in other polygynous species. In the few societies in which women wield substantial public power, as opposed to informal influence, they evidence no clear reproductive gain. In fact, in some of the examples, it is apparent that there is a conflict between political and direct reproductive gain for women. In matrilineal and double descent systems, women's power appears to accrue to their sons, who may reap reproductive benefit (Trivers, 1985; Low, 1992). In summary, through evolutionary history men have been able to gain reproductively by warring behavior; women almost never have been able to do so.

It is important to note that the argument does not hinge on sexual size dimorphism in humans-the fact that men are generally bigger and stronger than women. Even in ungulate species like red deer, in which status and resource control are mediated through physical combat, and there is no evidence of reciprocal "political" alliances, size is not the only determinant of status (e.g., Clutton-Brock et al., 1982). In primate species, and in human societies, the social complexities so far outweigh the impact of physical size that size alone is a poor predictor of success. Similarly, this argument does not reduce to an assertion that women are bound by the constraints of pregnancy, nursing and child care. If that were true, sterile women and postmenopausal women might broadly be expected to engage in intergroup conflict, as do other primate females.

Sexual dimorphism in use of resources and power in reproduction is the critical factor. Men appear to seek direct reproductive gain (e.g., stealing wives) in intergroup conflict, while women, when they are (rarely) involved, seek resources for themselves and their offspring. Sometimes this is accomplished through indirect or informal influence and nepotistic gain. Most commonly, the amount of resources controlled by women is just sufficient to support their family, although sometimes, particularly in matrilineal and duolineal societies (Low, 1993b), women may gain for their families. These societies, like the Cherokee and perhaps the Ashanti, are also those in which there is an occasional woman warrior.

\section{[3] Levels of Selection: Why We Are Not Environmental or Population Altruists}

A behavioral ecological perspective highlights a seldom-noted but crucial fact: only behaviors that enhance the success of a genetic lineage 
(such as behaviors which are selfish, parental, nepotistic, or reciprocal) can evolve by natural selection. "Genetic altruists" (those who, to their cost and others' benefit, restrict or cease reproduction, like the Shakers) decline in the population, being replaced by individuals that behave to their own reproductive benefit, as Darwin himself recognized (Darwin, 1859, p. 260).

Cuitural (as opposed to natural) selection can give rise to celibacy, suicide, and other reproductively unprofitable patterns. Because cultural patterns can be passed not only directly to descendants, but to any others who are interested, ideas and culturally-promoted behaviors can spread in very different patterns from genetically-transmitted traits (Boyd \& Richerson, 1985; Williams, 1992). Nothing prohibits the occurrence of a Mother Teresa or the Shakers with their rules of celibacy, but they are nonetheless unlikely to become or remain a majority of any population. Similarly, environmental strategies that require broad compliance and that carry an individual cost (or perceived cost) will have a difficult time.

To conservationists, the most familiar "levels of selection" problem is probably the "tragedy of the commons" (e.g., Hardin, 1968). In most cases, these situations involve resources to which all have access (and which, if destroyed, will hurt all), but which give short-term individual profit to those who exploit them. Typically, when many unrelated individuals simultaneously have common access to resources, whether the resources are grazing lands or whale populations, they tend to exploit the resource more than is wise from the community's longterm perspective, in order to gain personally. There are common-pool resource groups that manage their resources sustainably, over long periods of time-but they are typically small homogeneous groups, of stable (often kin-based) membership, with low wealth stratification (e.g., Ostrom, 1990; Ostrom, Gardner, \& Walker, 1992). In such groups the payoff for cheating on other group members is low, the benefits of a good reputation are high, and the rewards for defection are limited (see Ostrom, Walker, \& Gardner, 1992). The difficulty, as we look at large-scale problems that have some characteristics of commons, is that we cannot expect the sort of group-beneficial behavior that characterizes small kin groups to hold in large, heterogeneous groups. The larger, more diverse, and more fluid a group, the less one can count on convergence of individual and group interests to give us longterm sustainable behavior.

A popular normative approach is to suggest that we convince ourselves to live less consumptively (e.g., "Live Simply, That Others May Simply Live"). This was the dominant strategy of the 1970 s environmental movement and has considerable support today, but I suggest that there are 
strong theoretical reasons not to be sanguine about its effectiveness. Normative approaches rest on the assumption that we are willing to see our individual interests as converging with the interests of our larger group; and as I just noted, the conditions under which this assumption holds are limited. Many large-scale environmental problems should be rare if this assumption were true.

Can we extend reciprocity towards these environmental ends? No species has developed reciprocity to the extent humans have. Yet selection cannot favor individuals who act for the benefit of a group of nonrelatives at the expense of their own inclusive fitness; only behaviors which enhance reproductive success (such as behaviors which are selfish, parental, reciprocal, or help relatives and therefore enhance inclusive fitness) can evolve by natural selection. Many apparently reciprocal behaviors are in fact exploitation (e.g., Connor, 1995). Situations in which the costs are paid by individuals other than those gaining the rewards are unstable.

Behavioral ecology leads to a number of predictions: we expect resource control and consumption to be positively correlated under most conditions; we expect individuals to act in their own self-interest (though this is not always "self-interest" in the narrow economic sense; see Low, 1993a for review). It is not that altruistic behaviors will never occur; it is just that, because they cannot spread by natural selection, they will be rare. Thus, we expect only a small proportion of a population willingly to choose bicycles over Miatas, when both are available and affordable for the individual. Behavioral ecological theory suggests that normative approaches to both fertility and consumption decisions are likely to convince only a small fraction of people. When people are asked to do things that cost them individually in the short term, no matter how laudable and reasonable, there is considerable defection. Simply asking for altruism just has not worked as a widespread strategy. We still do not seem to have a clear idea of which strategies will work relatively well under what circumstances (Low \& Heinen, 1993), but this is an obvious area for fruitfui research.

\section{[4] Novel Evolutionary Environments}

In other species and in preindustrial human societies for which we have sufficient data, individuals who have more resources typically have greater reproductive success. But we live in a novel world, largely of our own making. Now, with birth control, we have broken the link between resource accumulation and inclusive fitness. If we evolved, like other organisms, to strive for resources for ourselves and our families, one powerful corollary is that we typically derive proximate rewards of satisfaction and 
BOBB! S. LOW

pleasure from that struggle. What we perceive has always been some proximate cue like pleasure or pride, although the reason the behavior persisted (or died out) was its effect on inclusive fitness. Whenever some behavior has an evolutionary history of reproductive advantage, and conditions change ("novel evolutionary events"), there is a possibility for that behavior to continue be driven by proximate cues that in the past correlated with reproductive advantage, even when the proximate cues are currently unhinged from that functional advantage.

Because no organism, including humans, has evolved to be aware of ultimate selective effect, but only of proximate cues, selection acts so that those things which enhance our survivorship or reproduction-forming friendships, having sex-tend to be perceived ("proximate cues") as pleasurable, and acts which typically detract from our survivorship or reproduction-getting burned-are perceived as unpleasant or painful. Novelty complicates this process. For example, in nature, sweet foods are seldom harmful, while sour and bitter tastes often indicate the presence of harmful alkaloids. Thus a preference for sweet tastes became widespread in omnivores, including humans. In natural situations, it was difficult to obtain sufficient sugar without other nutrients and fiber, to create problems of obesity. However, once we humans invented technologies for refining and concentrating sugar, we created foods that had enormous concentrations of sugar, breaking the selective link between sweet taste-the proximate cue-and good food source that led to enhanced survivorship and reproduction. But proximate cues drive the system, and selection simply filters out alternatives. So, today we retain a preference for sweet taste that can be counter-adaptive (health risks, and perhaps sexual selection).

We humans may well be in precisely the same situation with regard to the use and conservation of resources. Natural selection has shaped all living organisms (including humans) to exploit resources effectively, in competition with each other; our problem is that we are so good at itthrough our cleverness, we have created a novel evolutionary circumstance; we have such technology that the very behaviors we evolved to perform are those likely to ruin us.

\section{POPULATION, CONSUMPTION, AND ENVIRONMENT}

The above data and patterns suggest several things. First, humans, like all other species, have evolved to strive to increase their individual resource consumption so long as it has shown reproductive payoffs. Because we live in a novel environment (Low \& Heinen, 1993) with high techno- 
logical efficiency, the striving we evolved to do can in fact destroy the environment we live in, both locally and even, perhaps, globally. Yet in the evolutionary history of humans, selection appears to have been directional-one never had too many resources. Like sugar in the natural environment, all one could get was always best.

Other things being equal, the family lines of more fertile individuals in any species become a greater proportion of any population than those of less fertile individuals. In other species, two conditions lead to lower fertility: [1] harsh environmental conditions, in which individuals cannot achieve the conditions necessary for successful reproduction, and [2] highly competitive (often rich) environments, in which only well-invested superkids can become successful. ${ }^{3}$

Here is a clue, I think, to the diversity in patterns of fertility decline in the developing world. In today's environment, fertility is low in situations parallel to the two conditions for other species: [1] resources are so restricted that women's fertility declines and mortality increases, or [2] intense consumption of (often relatively rich) resources enhance children's success. The impacts on the environment of these two very different kinds of low fertility are quite different; and neither low fertility nor low consumption alone will necessarily lead to sustainability. This is why increased consumption so often accompanies reduced fertility.

Intellectually, we can perhaps see danger in continuing to strive for maxima, but there is likely to be considerable inertia; it may be difficult to convince ourselves in large numbers to "live simply" when consuming more yields more resources and often more status. The two sexes have different return curves for these activities. Women's resource use in traditional societies has been low-risk, low-but-predictable return, and thus more sustainable than men's high-risk, high-gain resource striving. If we could harness these evolved sex differences could we enhance sustainability? The data suggest it may prove difficult. The major ecological factor selecting for lowered fertility today, increased competitiveness in the environment, brings with it selection for increased per capita consumption. Both fertility and consumption contribute to unsustainable conditions. Thus, there is likely to be no easy answer to the question of how to promote both lower fertility and lower consumption.

Answering questions about the relationships among fertility and consumption, fertility and sustainability, and consumption and sustainability is difficult for several reasons, over and above the complexity of the relationships. Two major categories of difficulties are that inappropriate data are applied to questions, and that answers to quite different questions are inap- 
BOBBI S. LOW

propriately seen as alternative answers to the same question. For example, revisit for a moment the relationship between wealth and fertility discussed above. First, using GNP per capita and TFR (e.g., Birdsall, 1980), whatever it tells us, has nothing whatever to say about the kind of within-population variation that is measured for theoretical arguments. Yet these data are often cited as showing a general negative relationship between wealth and fertility, even though they are inappropriate for that question.

As an example of the second difficulty, how can it be true that both wealthy, well-educated women (Kasarda et al., 1986) and women on welfare have lower-than-average fertility? In fact, both findings are true, simply because fertility is not linearly related to wealth for women, and because the conflict for women between (economic) production and reproduction, discussed above, is not identical when women earn their own wealth (as in both examples here), and when they are simply married to wage earnersand published comparisons do not take that fact into account (see Low, 1993a; Low \& Clarke, 1993). In fact, wealth-fertility relationships for women will not be appropriately analyzed until we have data separating the fertility of women who earn their own wealth from women married to men who provide wealth. The obvious prediction is that the highest fertility will be shown by nonworking women married to wealthy men (e.g., as in Daly \& Wilson, 1983, Figure 12-5; or Low, 1990b).

\section{WOMEN, FERTILITY, AND CONSUMPTION IN DEVELOPING NATIONS}

In traditional human societies, as among other primates, men's resource acquisition, directed largely toward mating effort, tended to be high-risk, high-gain, while women's resource acquisition tended to be lowrisk, low-return, more sustainable-simply enough for herself and her healthy offspring. In the developing world, as competition for resources becomes more severe, and the effectiveness of monetary parental investment in helping children increases, the result is likely to be greater investment per child and a shift for women to market participation. In many societies, the conflict between work and parental investment capability may be even sharper for women than for men. Turke (1989) has argued that, as family and kinship networks are weakened (e.g., by spatial disruption), fertility falls. In these cases, older children and non-descendant relatives comprise a resource (nepotistic effort); when that resource declines, fertility is likely to fall. When monetary resources become central to chil- 
POPULATION AND ENVIRONMENT

dren's success, women may shift from traditional maternal investment patterns to market employment, typically with additional negative impact on fertility.

If the story ended there, we might face no sustainability problems. However, since the impetus to lower fertility is higher per capita investment in children, this pattern has a positive impact on per capita consumption. The investment level required to produce successful offspring varies with environment and specifically with the threshold level of investment required for a child's success - often a correlate of competition, and in this sense, precisely analogous to the proper use of the concept of $r$ - and K-selection. This can differ for parents in the same society. If poorer parents cannot substantially enhance their children's success, then we might expect what was once called "Mediterranean" investment, with larger families, concentration of resources in one or a few children, with others living with the family or leaving early (behavioral ecologists would call this an "alternate strategies" situation). Parents of high socioeconomic status might do better by investing more per child to allow them to be competitive with their peers (e.g., education, clothing, status acquisitions). The required investment may limit the number of children they can afford. Within subgroups, however, those with more than sufficient resources may be able to support additional children and still have all adequately invested (e.g., Hughes, 1988; Low \& Clarke, 1992; 1993).

The burden of providing enhanced investment for children typically involves women joining the work force, and in competitive markets, gaining more education to do so (e.g., McClamrock, this volume). Lowered fertility in this context means better infant and maternal survivorship-but also that increased consumption will likely follow.

\section{EVOLVED SEX DIFFERENCES AND WESTERN SOCIETY}

In other species, and across human cultures, there is a sexual dimorphism in resource acquisition, control, and use, and the pattern is that predicted by behavioral ecology. Men compete to control resources in order to get wives, and form coalitions with both relatives and nonrelatives; women compete to acquire resources to feed dependents, and form coalitions mainly with other members of the household. This is an obvious oversimplification; humans have elaborated the art of coalitions to a degree unknown in any other species; nepotism and coalitions can persist after the death of major participants; in many societies men can control the repro- 
BOBBI S. LOW

ductive destinies of not only their mates, but other female relatives, and so on. Nonetheless, the general pattern is clear, and ecological correlates exist.

Today, in western industrialized nations, women have great actual resource control; in some less developed nations (e.g., west Africa) women also control important resources. Women spend money earned jointly and by men, as well as money they themselves earn; women can inherit property. While women may be neither as numerous or as powerful as men in larger political arenas, they can hold political posts. Under past conditions, and in preindustrial societies, women did not profit reproductively from risky competition for great gains in resources and status, while men did (above). In our own society, the link between power/resources and reproductive success may well be weakened (see review by Low, 1993a).

Can the evolved sex differences be brought into service, towards the ends of sustainability? Today, investment in fewer high-quality offspring, rather than production of many, may be the strongest reproductive strategy (see also Rogers, 1992). In our society, having children does not help accrue resources, as it may have in some preindustrial societies. Infant and child mortality are low, and resources are typically divided through wills among children. Thus, the strategy of resource accumulation and family limitation is liable to remain strong. Under these conditions of low fertility and high per capita consumption, women's access to resources and power may enhance family resources without a serious cost to net reproductive fitness-though women's accrual of resources in market economies clearly has net fertility costs (e.g., Kasarda, et al. 1986).

The difficulty those of us in the evolutionary fields see is that, rather than men becoming more like women in resource use, seeking sustainable levels of resources, enough to raise physically healthy children, the issue of competitiveness of the environment, I suspect, will lead women to act more like men have in past environments, seeking wealth, power, and status as proximate rewards for striving in a low-fertility society-resources, like Everest, to be mastered because they are there. Thus, what many of us working in this area find distressing is that as fertility falls, world markets emerge, technology advances, and women compete in the same urban market places as men, women's consumption patterns begin to look more like men's (though this is not well-documented; work needs to be done). Simplistic pleas for lower consumption are unlikely to work better in industrial societies when directed at women than at men. In an evolutionarily novel environment, this may not be surprising, but it may become problematic.

An array of strategies are used in the developed world to convince 
ourselves to reduce our per capita consumption: exhortation, information about consequences, manipulation of social costs and benefits for different consumption behaviors, and manipulation of economic and legal costs and benefits. We are still in the very early stages of finding effective matches for strategies and problems (Low \& Heinen, 1993). Strategies include [a] exhortation to "do the Right Thing," information about costs and benefits most likely to work when benefits and costs accrue to the same individuals, without great time lag); and [b] manipulation of costs (e.g., taxes, "polluter-pays" laws) and benefits (tax breaks and subsidies). It seems likely to be very difficult to get easy agreement on just what constitutes appropriate resource-consumption behavior (the levels of selection problem above, leading to individuals seeking to externalize the costs of their consumption). With regard to specifics of particular strategies that are effective for women, we face an entirely new challenge. In arenas such as this, we seek the proximate correlates of success, and the most useful work will come not from behavioral ecology, but from sociology and psychology.

\section{ENDNOTES}

1. The behavioral ecology of fertility has many echoes in a set of demographic arguments: various "individual decision" and "proximate variables" demographic models (e.g., Becker, 1981; Becker and Lewis, 1974; Easterlin, 1978; Tilly, 1978; Lindert, 1978; Simon, 1974; Lesthaeghe and Wilson, 1986), to Mosk's (1983) "leveraging" approach to interpreting fertility behavior, and to Easterlin and Crimmins's (1985) models of the factors favoring a shift to conscious control of fertility (reviewed by Low et al 1992). All have two important characteristics: individuals are not assumed to be uniform, and there is an explicit tradeoff between quantity and "quality" of children. An additional merit of such models may be that they are very general, applicable to all sexually-reproducing organisms, and not particular to one or another society or to one or another currency.

2. Several of these are problems for which sociology has no guidance, while behavioral and evolutionary approaches offer clear and testable theory: sex-preferential infanticide (Dickemann 1979); sex ratio and resources (Voland 1990); sex differences in reproduction and striving (Low 1988, 1990b), including the difference in remarriage rates between widows and widowers (Low 1991), and how wealth affects the lifetime reproduction of men versus women (Low and Clarke 1992); birth order and parental investment (Boone 1988); how Fisher's concept of reproductive value influences men's as opposed to women's reproductive choices (Low 1991); how interbirth interval and sex of child might be related (Low 1991).

3. Behavioral ecological arguments are based on the relative reproductive costs and benefits of individuals; they do not require that a specific gene be postulated as underlying any behavior. Rather, behavioral ecologists ask: Under what environmental conditions does a behavior arise and persist? Who does it? Whom does it profit? What is its impact on each individual's lineage success? Even in the case of many simple behaviors, selection has apparently operated on complexes of loci, many of which affect other behaviors. External environment and genes interact during development in a complex way. For many important behaviors, behavioral ecologists cannot specify the genetic loci involved (e.g., Grafen 1984); they study the correlations between the trait and environmental conditions. Often 
BOBBI S. LOW

one can make powerful and unexpected predictions from these correlations, using selection theory (e.g., see Krebs/Davies 1991; Daly/Wilson 1983).

\section{REFERENCES}

Abernethy, V. \& Yip, R. (1990). Parent characteristics and sex differential infant mortality: The case in Tennessee. Human Biology, 62(2), 279-290.

Alexander, R. D. (1987). The biology of moral systems. New York: Aldine De Gruyter.

Barkow, J. H. (1977). Conformity to ethos and reproductive success in two Hausa communities: An empirical evaluation. Ethos, 5, 409-425.

Barry, H., III, Josephson, L., Lauer, E. \& Marshall, C. (1976). Traits inculcated in childhood: Cross-cultural codes 5. Ethnology, 15, 83-114.

Becker, Gary S. (1981). A Treatise on the family. Cambridge: Harvard University Press.

Becker, Gary S. \& Lewis, Gregg H. (1974). Interaction between quantity and quality of children. In T. W. Schultz (Eds.). Economics of the family: Marriage, children and human capital pp. 81-90. Chicago: Chicago Univ. Press.

Betzig, L. L. (1986). Despotism and differential reproduction: A Darwinian view of history. New York: Aldine.

Betzig, L. L. \& Lombardo, L. H. (1991). Who's pro-choice and why. Ethology and Sociobiology, 13, 49-71.

Bideau, A. (1980). A demographic and social analysis of widowhood and remarriage: The example of the Castellany of Thoissey-en-Dombes 1670-1840. J. Family History, 5(1), $28-43$.

Bideau, A. \& Perrenoud, A. (1981). Remariage et fécondité. Contribution à l'étude des mécanismes de récuperation des populations anciennes. In J. Dupâquier, E. Hélin, P. Laslett, M. Livi-Bacci \& S. Sogner (Eds.). Marriage and remarriage in populations of the Past pp. 547-559. New York: Academic Press.

Birdsall, N. (1980). Population growth and poverty in the developing world. Population Bull. $35,3-46$.

Blurton Jones, N. G. \& Konner, M. J. (1973). Sex differences in the behavior of Bushman and London two-to five-year-olds. In J. Crook \& R. Michael (Eds.). Comparative ecology and Behavior of primates. New York: Academic Press.

Boone, J. L., III. (1986). Parental investment and elite family structure in preindustrial states: A case study of late medieval-early modern Portuguese genealogies. Amer. Anthropol., 88, 859.

Boone, J. L., III. (1988). Parental investment, social subordination and population processes among the 15 th and 16 th century Portuguese nobility. In L. Bertig \& $\mathrm{M}$. Borgerhoff Mulder \& P. Turke (Eds.). Human reproductive behaviour: A Darwinian perspective pp. 201 220. Cambridge: Cambridge University Press.

Boswell, J. (1990). The kindness of strangers: The abandonment of children in Western Europe from late Antiquity to the renaissance. NY: Vintage Press.

Botkin, D. B. (1990). Discordant harmonies: A new ecology for the twenty-first century. Oxford: Oxford University Press.

Boyd, R. \& Richerson, P. J. (1985). Culture and the evolutionary Process. Chicago: University of Chicago Press.

Bugos, P. E. \& McCarthy, L. M. (1984). Ayoreo infanticide: A case study. In G. Hausfater \& S. B. Hrdy (Eds.). Infanticide: Comparative and evolutionary perspectives, pp. 503-520. New York: Aldine.

Cabourdin, G. (1981). Le remariage en France sous l'ancien régime (seizième-dix-huitième siècles). In \}. Dupâquier, E. Hélin, P. Laslett, M. Livi-Bacci \& S. Sogner (Eds.). Marriage and remarriage in populations of the past pp. 273-285. New York: Academic Press. 
Cain, M. (1985). On the relationship between landholding and fertility. Population Studies, $39,5-15$.

Caldwell, J. C. (1976). Toward a restatement of demographic transition theory, Population and Development Review, 2, 321-366

Caldwell, J. C. (1983). Direct economic costs and benefits of children. In R. A. Bulatao \& R. D. Lee (Eds.). Determinants of fertility in developing countries, volume l, pp. 458-493. New York: Academic Press.

Chagnon, N. A. (1979). Is reproductive success equal in egalitarian societies? In N. A. Chagnon \& W. Irons (Eds.). Evolutionary biology and human social behavior: An anthropological perspective. North Scituate, MA: Duxbury.

Chagnon, N. A. (1982). Sociodemographic attributes of nepotism in tribal populations: Man the rule-breaker. In Kings' College Sociobiology Group (Eds.). Current problems in sociobiology. Cambridge: Cambridge University Press.

Chagnon, N. A. (1988). Life histories, blood revenge, and warfare in a tribal population. Science, 239, 985-992.

Clutton-Brock, T. H., Guinness, F. \& Albon, S. (1982). Red deer: Behavior and ecology of two sexes. Chicago: University of Chicago Press.

Coale, A,.$(1986)$. The decline of fertility in Europe since the eighteenth century as a chapter in human demographic history. In A. J. Coale \& S. C. Watkins (Eds.). The decline of fertility in Europe. Princeton: Princeton University Press.

Coleman, D. \& Schofield, R. S. (Eds.). (1986). The state of population theory: Forward From Malthus. London: Basil Blackwell.

Connor, R. C. (1995). The benefits of mutualism: A conceptual framework. Biol. Rev. 70, $427-457$.

Corsini, C. A. (1981). Why is remarriage a male affair? Some evidence from Tuscan villages during the eighteenth century. In J. Dupâquier, E. Hélin, P. Laslett, M. Livi-Bacci \& S Sogner (Eds.). Marriage and remarriage in populations of the past, pp. 385-395. New York: Academic Press.

Cronk, Lee. (1991a). Wealth, status, and reproductive success among the Mukogodo of Kenya. Amer. Anthropol., 93(2), 345-360.

Cronk, Lee. (1991b). Human behavioral ecology. Ann. Review Anthropol., 20, 25-53.

Daly, M. \& Wilson, M. (1983). Sex, evolution, and behavior, 2nd edition. Boston: Willard Grant.

Daly, M. \& Wilson, M. (1984). A sociobiological analysis of human infanticide. In G. Hausfater \& S. B. Hrdy (Eds.). Infanticide: Comparative and evolutionary perspectives, pp. 487502. New York: Aldine.

Daly, M. \& Wilson, M. (1985). Child abuse and other risks of not living with both parents. Ethology and Sociobiology, 6, 197-210.

Daly, M. \& Wilson, M. (1987). Children as homicide victims, In R. J. Gelles \& Jane B. Lancaster (Eds.). Child abuse and neglect: Biosocial Dimensions, pp. 201-214. New York: Aldine

Daly, M. \& Wilson, M. (1988). Homicide. New York: Aldine de Gruyter.

Darwin, C. (1859). On the origin of species by means of natural selection. Facsimile of the first edition with an introduction by Ernst Mayr. Cambridge, MA: Harvard University Press.

Darwin, C. (1871). The descent of man, and selection in relation to sex, 2 volumes. John Murray.

Dawkins, R. (1982). The extended phenotype: The gene as the unit of selection. San Francisco: W. H. Freeman.

Dawkins, R. (1989). The selfish gene, new edition. Oxford: Oxford University Press.

Dickemann, M. (1979). Female infanticide, reproductive strategies, and social stratification: A preliminary model. In N. A. Chagnon \& W. Irons (Eds.). Evolutionary biology and human social behavior: An anthropological perspective, pp. 321-367. North Scituate, MA: Duxbury. 
BOBBI S. LOW

Drake, M. (1969). Population and society in Norway: 1735-1865. Cambridge: Cambridge University Press.

Dupâquier, J. (1972). De l'animal à l'homme: Le mechanisme autorégulateur des populations traditionelles. Rev. de L'Institute de Sociologie de L'Université Libre de Bruxelles, 2, 177-211.

Durning, A. T. (1994). The conundrum of consumption. In L. A. Mazur (Ed.). Beyond the numbers: A reader on Population, Consumption, and the Environment, pp. 40-48. Washington, DC: Island Press.

Easterlin, R. (1978). The economics and sociology of fertility: A synthesis. In Charles Tilly (Ed.). Historical studies of changing fertility, pp. 57-134. Princeton: Princeton University Press.

Easterlin, R. \& Crimmins, E. M. (1985). The fertility revolution: A supply-demand analysis. Chicago: University of Chicago Press.

Ember, C. R. (1981). A cross-cultural perspective on sex differences. In R. H. Monroe, R. L. Monroe \& B. B. Whiting (Eds.). Handbook of cross-cultural human development, pp. 531-580). Garland.

Fadiman, 1. A. (1982). An oral history of tribal warfare: The Meru of Mt. Kenya. Cleveland: Ohio University Press.

Fisher, R. A. (1958). The genetical theory of natural selection, 2nd revised edition. New York: Dover Books.

Flinn, M. V. (1986). Correlates of reproductive success in a Caribbean village. Human Ecology, 14, 225-243.

Freedman, D. G. (1974). Human infancy: An evolutionary perspective. Erlbaum Press.

Freedman, D. S. \& Thornton, A. (1982). Income and fertility: The elusive relationship. Demography, 19(1), 65-78.

Fuchs, R. (1984). Abandoned children: Foundlings and child welfare in nineteenth-century France. SUNY Press.

Glick, P. C. \& Lin, S-L. (1986). Recent changes in divorce and remarriage. J. Marriage and the Family, 48, 737-747.

Grafen, A. (1984). Natural selection, kin selection, and group selection. In J. R. Krebs \& N. B. Davies (Eds.). Behavioural ecology: An evolutionary approach. Blackwell Scientific.

Griffith, J. D. (1980). Economy family and remarriage: Theory of remarriage and application to preindustrial England. J. Family Issues, 1(4), 479-496.

Hardin, G. (1968). The tragedy of the commons. Science 162: 1243-1248.

Hartung, J. (1982). Polygyny and the inheritance of wealth. Current Anthropol., 23, 1-12.

Hartung, J. (1983). In defense of Murdock: A reply to Dickemann. Current Anthropol., 24(1), $125-126$

Hawkes, K. \& Charnov, E. L. (1988). Human fertility: Individual or group benefit? Current Anthropol., 20, 469-471.

Hawkes, K., O'Connell, J. F., \& Blurton Jones, N. G. (1989). Hardworking Hadza grandmothers. In V. Standen \& R. A. Foley (Eds.). Comparative socioecology, Blackwell.

Hayami, A. (1980). Class differences in marriage and fertility among Tokugawa villagers in Mino Province. Keio Economic Studies, 17(1), 1-16.

Hill, E. \& Low, B. (1991). Contemporary abortion patterns: A life-history approach. Ethology and Sociobiology, 13,35-48.

Hill, J. (1984). Prestige and reproductive success in man. Ethology and Sociobiology, 5, 77-95.

Hill, K. \& Kaplan, H. (1988). Tradeoffs in male and female reproductive strategies among the Ache. In L. Betzig, M. Borgerhoff Mulder \& P. W. Turke (Eds.). Human reproductive behaviour: A Darwinian Perspective, pp, 277-289. Cambridge: Cambridge University Press

Hrdy, S. B. (1974). Male-male competition and infanticide among the lemurs (Presbytis entellus) of Abu Rajasthan. Folia Primatol, $22,19-58$.

Hrdy, S. B. (1978). Allomaternal care and the abuse of infants among Hanuman langurs. In D. J. Chivers \& P. Herbert (Eds.). Recent advances in primatology, volume 1. New York: Academic Press. 


\section{POPULATION AND ENVIRONMENT}

Hrdy, S. B. (1979). Infanticide among animals: A review classification and implications for the reproductive strategies of females. Ethology and Sociobiology, 1, 13-40.

Hughes, A. L. (1986). Reproductive success and occupational class in eighteenth-century Lancashire England. Social Biology, 33, 109-115.

Hughes, A. L. (1988). Evolution and human kinship. Oxford: Oxford University Press.

Imhof, A. E. (1981). Remarriage in rural populations and in urban middle and upper strata in Germany from the sixteenth to the twentieth century. In J. Dupâquier, E. Hélin, P. Laslett, M. Livi-Bacci \& S. Sogner (Eds.). Marriage and remarriage in populations of the past, pp. 335-346. New York: Academic Press.

Irons, W. (1979). Cultural and biological success. In N. A. Chagnon \& W. Irons (Eds.). Evolutionary biology and human social behavior: An anthropological perspective. North Scituate, MA: Duxbury.

Johnson, N. E. \& Lean, S. (1985). Relative income, race, and fertility. Population Studies, 39, 99-112.

Kaplan, H. \& Hill, K. (1985). Hunting ability and reproductive success among male Ache foragers: Preliminary results. Current Anthropology, 26, 131-133.

Kaplan, $H$. et al. in press. Fertility and fitness among Albuquerque men: A competitive labour market theory. In Proceedings of the Galton Institute Symposium. MacMillan.

Kasarda, John D., Billy, J. O. G. \& West, K. (1986). Status enhancement and fertility: Reproductive responses to social mobility and educational opportunity. New York: Academic Press.

Knodel, J. (1981). Remarriage and marital fertility in Germany during the eighteenth and nineteenth centuries: An exploratory analysis based on German village genealogies. In J. Dupâquier, E. Hélin, P. Laslett, M. Livi-Bacci \& S. Sogner (Eds.). Marriage and remarriage in populations of the past. New York: Academic Press.

Knodel, J. \& Lynch, K. A. (1985). The decline of remarriage: Evidence from German village populations in the eighteenth and nineteenth centuries. J. Family History, 10(1), 34-59.

Knodel, J., Havanon, N. \& Sittitrai, W. (1990). Family size and the education of children in the context of rapid fertility decline. Population and Development Review, 16(1), 31-62.

Krebs, J. R. \& Davies, N. B. (Eds). (1991). Behavioural ecology: An evolutionary approach, 3rd edition. Blackwell Scientific.

Lancaster, J. B. \& Lancaster, C. S. (1987). The watershed: Change in parental-investment and family-formation in the course of human evolution. In Lancaster ). B. et al. (Eds.). Parenting across the life span: Biosocial dimensions, pp. 187-205. New York: Aldine de Gruyter.

Le Boeuf, Burney \& Reiter, Joanne. (1988). Lifetime reproductive success in northern elephant seals. In T. H. Clutton-Brock (Ed.). Reproductive success: Studies of individual variation in contrasting breeding systems, pp. 344-383. Chicago: University of Chicago Press.

Lesthaeghe, R., and Wilson, C. (1986). Modes of production, secularization, and the pace of fertility decline in western Europe, 1870-1930. In A. 1. Coale and S. C. Watkins (Eds.). The decline of fertility in Europe. Princeton: Princeton University Press.

Lindert, P. H. (1978). Fertility and scarcity in America. Princeton: Princeton University Press.

Low, Bobbi S. (1988). Measures of polygyny in humans. Current Anthropology, 29(1), 189194.

Low, Bobbi S. (1989a). Occupational status and reproductive behavior in 19th century Sweden: Locknevi parish. Social Biology, 36, 82-101.

Low, Bobbi S. (1989b). Cross-cultural patterns in the training of children: An evolutionary perspective. J. Comparative Psychology, 103(4), 311-319.

Low, Bobbi S. (1990a). Occupational status, land ownership, and reproductive behavior in 19th century Sweden: Tuna parish. Amer. Anthropologist, 92(2), 457-468.

Low, Bobbi S. (1990b). Sex, power, and resources: Male and female strategies of resource acquisition. Intl. J. Contemp. Sociol., 27, 45-71.

Low, Bobbi S. (1991). Reproductive life in 19 th century Sweden: An evolutionary perspective on demographic phenomena. Ethology and Sociobiology, 12, 411-468. 
BOBBI S. LOW

Low, Bobbi S. (1992). Sex, coalitions, and politics in pre-industrial societies. Politics and the Life Sciences, 11(1), 63-80.

Low, Bobbi S. (1993a). Ecological demography: A synthetic focus in evolutionary anthropology. Evolutionary Anthropology, 1(5), 177-187.

Low, Bobbi S. (1993b). An evolutionary perspective on war. In H. Jacobson \& W. Zimmerman (Eds.). Behavior, Culture, and Conflict in World Politics (Chapter 1). Ann Arbor: U. Michigan Press.

Low, Bobbi S. (1994a). Men in the demographic transition. Human Nature 5(3), 223-253.

Low, Bobbi S. (1994b) Human sex differences in behavioral ecological perspective. Analyse \& Kritik 16, 38-67.

Low, Bobbi S. \& Clarke, Alice L. (1991). Family patterns in nineteenth-century Sweden: Impact of occupational status and landownership. J. Family History, 16(2), 117-138.

Low, Bobbi S. \& Clarke, Alice L. (1992). Resources and the life course: Patterns in the demographic transition. Ethology and Sociobiology, 13(5-6), 463-494.

Low, Bobbi S. \& Clarke, Alice L. (1993). Historical perspectives on population and environment: Data from 19th century Sweden. In Gayl Ness \& William Drake (Eds.). Populationenvironment dynamics: Theory and data, pp. 195-224. Ann Arbor: U. Michigan Press.

Low, Bobbi S., Clarke, Alice L. \& Lockridge, K. (1992). Toward an ecological demography. Population and Development Review, 18(1), 1-31.

Low, Bobbi S., \& Heinen, J. T. (1993). Population, resources, and environment. Population and Environment 15(1), 7-41.

MacArthur, R. H. \& Wilson, E. O. (1967). The theory of island biogeography. Princeton: Princeton University Press.

MacKellar, F. L. \& Hatcher, D. E. (1994). Population, living standards and sustainability: An economic view. In L. A. Mazur (Ed.). Beyond the numbers: A reader on population, consumption, and the environment, pp. 76-92. Washington, DC: Island Press.

Manson, !. \& Wrangham, R. (1991). Intergroup aggression in chimpanzees and humans. Current Anthropology, 32, 369-390.

Mclnnis, R. M. (1977). Childbearing and land availability: Some evidence from individual household data. In R. Lee (Ed.). Population patterns in the past, pp. 201-227. Academic Press.

Mello, F. V. (1994). Sustainable development for and by whom? In L. A. Mazur (Ed.). Beyond the numbers: $A$ reader on population, consumption, and the environment, pp. 71-76. Washington, DC: Island Press.

Mosk, C. (1983). Patriarchy and fertility: Japan and Sweden, 1880-1960. New York: Academic Press.

Mueller, U. (1991). Social and reproductive success. Theoretical considerations and a case study of the West Point Class of 1950. ZUMA: Zentrum für Umfragen, Methoden und Analysen.

Omark, D. R. \& Edelman, M. S. (1975). A comparison status hierarchy in young children: An ethological approach. Soc. Sci. Infor., 14, 87-107.

Ostrom, E. (1990). Governing the commons: The evolution of institutions for collective action. Cambridge: Cambridge University Press.

Ostrom, E., Walker, J., \& Gardner, R. (1992). Covenants with and without a sword: Selfgovernance is possible. American Political Science Review, 86(2), 404-417.

Ostrom, E., Gardner, R. \& Waiker, 1. (1992). Rules, games, and common-pool resources. Blommington, IN: Workshop on Political Theory and Analysis.

Packer, C. \& Pusey, A. E. (1983). Adaptations of female lions to infanticide by incoming males. Amer. Naturalist, 121, 716-728.

Packer, C. \& Pusey, A. E. (1984). Infanticide in carnivores. In C. Hausfater \& S. B. Hrdy (Eds.). Infanticide: comparative and evolutionary perspectives. New York: Aldine.

Parry, J. P. (1979). Caste and kinship in Kangara. London: Routledge \& Paul.

Pérusse, D. (1992). Cultural and reproductive success in industrial societies: Testing the relationship at the proximate and ultimate levels. Behavioral and Brain Sciences. 


\section{POPULATION AND ENVIRONMENT}

Pfister, U. (1989a). Proto-industrialization and demographic change: The Canton of Zurich revisited. J. Economic History, 18, 629-662.

Pfister, U. (1989b). Work roles and family structure in proto-industrial Zurich. J. Interdisciplinary History, 20, 83-105.

Rank, M. A. (1989). Fertility among women on welfare: Incidence and determinants. Amer. Sociological Review, 54, 296-304.

Ransel, D. (1988). Mothers in misery: Child abandonment in Russia. Princeton: Princeton University Press.

Rogers, A. R. (1990). The evolutionary economics of human reproduction. Ethology and Sociobiology, 11, 479-495.

Rogers, A. R. (1991). Conserving resources for children. Human Nature, 2(1), 73-82.

Rogers, A. R. (1992). Resources and population dynamics. In E. A. Smith \& B. Winterhalder (Eds.). Evolutionary ecology and human behavior, pp. 375-402. New York: Aldine de Gruyter.

Rosenblatt, P. \& Cunningham, M. R. (1976). Sex differences in cross-cultural perspective. In B. B. Lloyd \& J. Archer (Eds.). Explorations in sex differences. New York: Academic Press.

Schofield, R. S. (1976). The relationship between demographic structure and environment in pre-industrial Western Europe. In W. Conze (Ed.). Die Sozialgeschichte der Familie in der Neuzeit Europas. Stuttgart: Ernst Klett.

Shaw, R. Paul (1985). Humanity's propensity for warfare: A sociobiological perspective. Canadian Rev. Soc. Anthrop., 22, 159-183.

Shaw, R. Paul \& Wong, Y. (1989). The genetic seeds of warfare: Evolution, nationalism, and patriotism. Unwin Hyman.

Sherwood, J. (1988). Poverty in eighteenth-century Spain: Women and children of the Inclusa. Toronto: University of Toronto Press.

Simon, ). L. (1974). The effects of income on fertility. Chapel Hill, NC: Carolina Population Center.

Tilly, Charles. (1978). The historical study of vital processes. In Charles Tilly (Ed.). Historical studies of changing fertility, pp. 1-55. Princeton: Princeton University Press.

Trivers, R. L. (1985). Social evolution. Benjamin Cummings.

Turke, P. W. (1988). Helpers at the nest: Childcare networks in Ifaluk. In Betzig, L., Borgerhoff Mulder, M., \& Turke. P. (Eds.), Human reproductive behaviour: A Darwinian perspective. Cambridge: Cambridge University Press.

Turke, P. W. (1989). Evolution and the demand for children. Population and Development Review, 15(1), 61-90.

Turke, P. W. (1992). Theory and evidence on wealth flows and old-age security: A reply to Fricke. Population and Development Review, 17(4), 687-702.

Turke, P. W. \& Betzig, L. L. (1985). Those who can do: Wealth status and reproductive success on Ifaluk. Ethology and Sociobiology, 6, 79-87.

Viazzo, P. P. (1990). Upland communities: Environment, population, and social structure in the Alps since the sixteenth century. Cambridge: Cambridge University Press.

Voland, E. (1984). Human sex-ratio manipulation: Historical data from a German parish. $J$. Human Evolution, 13, 99-107.

Voland, E. (1989). Differential parental investment: Some ideas on the contact area of European social history and evolutionary biology. In V. Standen \& R. A. Foley (Eds.). Comparative socioecology: The behavioural ecology of humans and other mammals, pp. 391402. Special Publ. 8. The British Ecological Society.

Voland, E. (1990). Differential reproductive success within the Krummhörn population (Cermany, 18 th and 19th centuries). Behav. Ecol. and Sociobiol., 26, 65-72.

Whiting, B. \& Edwards, C. P. (1973). A cross-cultural analysis of sex differences in the behavior of children aged three through eleven. J. Social Psychology, 91, 171-188.

Whiting, B.\& Whiting, J. (1975). Children of six cultures: A psychocultural analysis. Cambridge, MA: Harvard University Press.

Williams, George. (1966). Adaptation and natural selection. Princeton: Princeton University Press. 
BOBBI S. LOW

Williams, George. (1992). Natural selection: Issues, domains, and challenges. Oxford University Press.

Wilson, E. O. (1975). Sociobiology. Cambridge, MA: Harvard University Press.

Wrigley, E. A. (1978). Fertility strategy for the individual and the group. In C. Tilly (Ed.). Historical studies of changing fertility. Princeton: Princeton University Press.

Akerman, S. (1981). The importance of remarriage in the seventeenth and eighteenth centuries. In J. Dupâquier, E. Hélin, P. Laslett, M. Livi-Bacci \& S. Sogner (Eds.). Marriage and remarriage in populations of the past, pp. 163-175. New York: Academic Press. 